\title{
THE ACCEPTANCE AND USE OF THE E-LEARNING SYSTEMS AMONG THE UNIVERSITY TEACHERS IN ECUADOR
}

\author{
R. Ramirez-Anormaliza ${ }^{1}$, F. Sabaté ${ }^{2}, X$. Llinàs-Audet ${ }^{2}$ \\ ${ }^{1}$ Universidad Estatal de Milagro (ECUADOR) \\ ${ }^{2}$ Universitat Politècnica de Catalunya (SPAIN)
}

\begin{abstract}
The success of an e-learning system depends largely on the acceptance and use that teachers give this tool. After critically evaluate models of technology adoption, including the Technology Acceptance Model (TAM) and TAM2, we built a conceptual model to predict the level of acceptance and use of elearning system among teachers. This model extends TAM2 and includes technical support, computer self-efficacy, social influence, perceived enjoyment and satisfaction. Data were collected from 145 teachers of a University in Ecuador. For data collection, a form in Likert scale was sent by email. Upon receipt of the data, these missing data reported $4.2 \%$, to correct this data imputation method it was applied for replacement by mean. After performing the checks about satisfactory reliability and validity, the structural model was tested using PLS. The results indicate that perceived ease of use and perceived usefulness have a direct effect on the intension of using e-learning systems. Perceived enjoyment, perceived ease of use and social influence have a direct effect on the perceived usefulness. Perceived enjoyment and computer self-efficacy both have a direct effect on perceived ease of use of e-learning systems. Universities Principals should not only worry about the basic design of e-learning systems, but also explicitly address individual differences among teachers using elearning system.
\end{abstract}

Keywords: e-learning, TAM, PLS.

\section{INTRODUCTION}

Information and communication technologies (ICT) facilitates data processing and distribution of information via electronic [1]. The e-learning systems are the use of ICT for teaching [2]. The use of elearning systems and corporate training are carried out in institutions of higher education [2], [3].

The development of the World Wide Web (WWW) has become an essential tool in education due to its ability to allow the exchange of hypermedia information [4].

The e-learning systems Moodle, Blackboard and WebCT, etc.; provide new methods and ways of teaching through the WWW [5]. These systems are used in order to strengthen courses (face-to-face and distance) [6], [7].

Recent research on the acceptance and use of e-learning systems, show negative results related to a high percentage of teachers in which the benefits of these tools are not reflected, despite the increase in the market for these systems [8].

Internet is a global and widely used technology, but its effectiveness should be measured at local levels, since users often work in local / national contexts [9]. Therefore, it was important to investigate the acceptance of e-learning systems among teachers in Ecuador.

It was identified that in Latin America there are a few studies like this, so it was considered relevant to perform this research in the university context of Ecuador in order to establish a model to predict the acceptance of e-learning systems among university teachers in Ecuador.

Since the mid-eighties, research has been conducted with greater emphasis to measure the acceptance of technology. In 1986 the technology acceptance model (TAM) was proposed [10]. TAM is based on the theory of reasoned action of Fishbein and Ajzen. TAM was enhanced up to version 2 shown in Fig.1 [11]-[14]. 


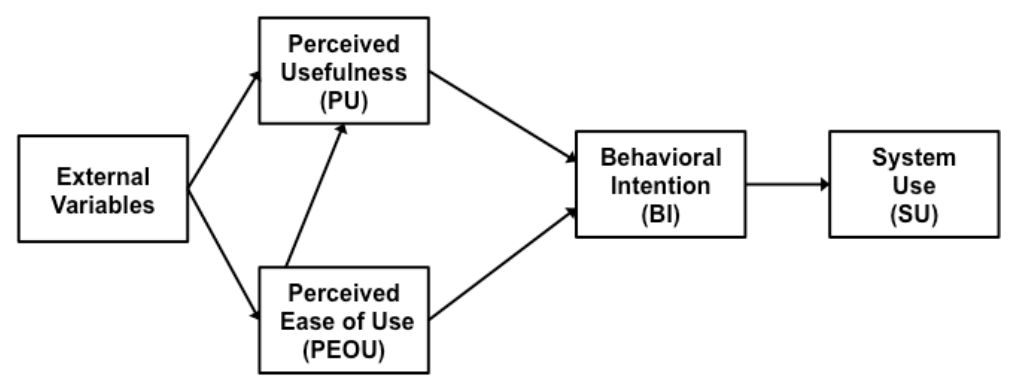

Fig. 1. TAM 2 [14]

TAM is the most widely used framework for assessing acceptance of technology [15], however in studies of the acceptance and use of e-learning systems it is of recent use [16]. Despite its widespread diffusion, researchers argue that you can still work on this [17]; therefore, for this study it is used in the context of Ecuador.

For TAM, the user's attitude towards the use of an information system is shown as a function of the constructs usefulness perceived (PU) (the degree to which a person believes that using a particular system could improve its performance work) and perceived ease of use (PEOU) (the degree to which a person believes that using a particular system would be free of effort) [18].

For TAM, external variables directly affect on PU and PEOU, these external variables provide a better understanding of what influences on PU and PEOU [10]. Therefore, the perceived usefulness and perceived ease of use have played an important role in decisions affecting technology adoption [19].

In previous research (like this one), the most used technique was the structural equation model (SEM). This technique relates latent variables (constructs or variables that are not observed directly), with indicators or items that are directly observable [20].

The aim of this research was to adapt a model to predict the use and intending use of e-learning systems among Ecuadorian teachers based on TAM.

\section{RESEARCH MODEL AND HYPOTHESES}

In reviewing the evolution of TAM applied to evaluate the acceptance of e-learning systems, various constructs and items were chosen. The items were adapted to our study. Then the selected constructs and adapted items were submitted to the opinion of four experts. This process suggested us five constructs. In addition to those already defined by TAM. These were:

- Social influence (SI), defined as the change in thoughts, feelings, attitudes or behavior of an individual that results from the interaction with another individual or group [21].

- Perceived Enjoyment (PE), is defined as: the extent to which the activity of using the technology is perceived to be enjoyable in its own right, apart from any performance consequences that may be anticipated [22].

- Technical support (TS), defined as people trained to help users in solving problems related to computer hardware and software, in the form of help desks, hot lines for complaints and suggestions, technical support on-line, by fax, telephone, etc. [23].

- Computer Self-efficacy (CSE), is defined as an individual judgment of efficacy across multiple computer domains and application-specific self-efficacy is defined as an individual perception of efficacy in using a specific application or system within the domain of general computing [24].

- Satisfaction (S), in the context under study, user satisfaction is the degree to which the elearning system meets their information needs [25].

The relationship between the five external variables presented and PU - PEOU as the framework study are shown in Fig 2. Hypotheses are presented below:

- H1, H2.1, H3.1, H4.1, H5.1: PU is positively influenced by SI, PE, TS, CSE and PEOU.

- H2.2, H3.2, H3.2, H4.2: PEOU is positively influenced by PE, TS and CSE.

- H6.2, H5.2: BI is positively influenced by PEOU and PU. 
- H6.1: $\mathrm{S}$ is positively influenced by PU.

- H7.0, H8.0: SU is positively influenced by $S$ and BI.

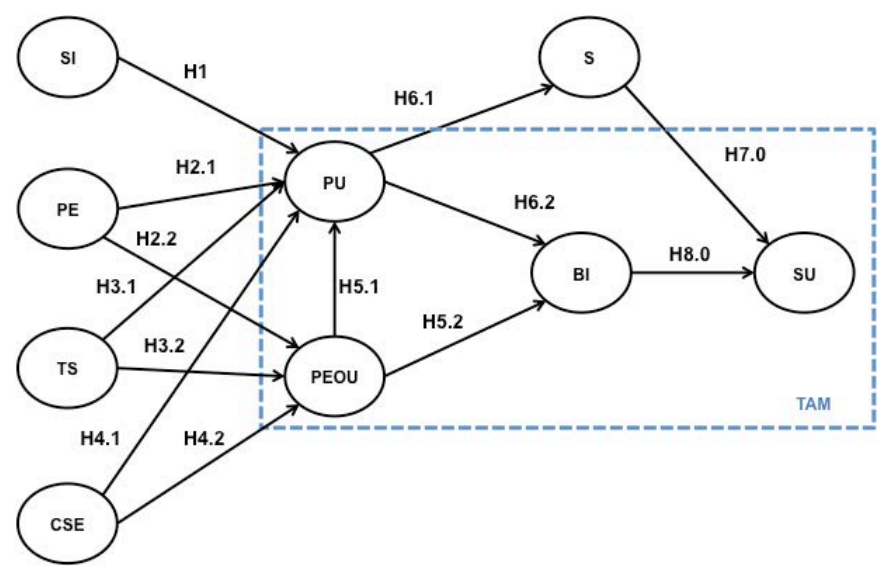

Fig. 2. Research model

\section{METHODOLOGY}

The survey research was applied to 200 teachers in 2015. This survey included 52 items, using a standard seven-point Likert scale ranging from "strongly disagree" to "strongly agree" (see Table 1). The items were used, based on previously published scales for the various constructs.

Teachers surveyed used the Moodle e-learning platform in a University of Ecuador. Their participation was voluntary and no financial incentive was offered. A web system at the same university was used to collect data electronically.

A total of 145 responses were completed (response rate $72.5 \%$ ). Cases with missing data between $12 \%$ and $90 \%$ were eliminated from the study, 14 cases were eliminated. 105 cases were submitted without missing data.

Table 1 Constructs - items

\begin{tabular}{ll}
\hline Constructs - items & Source \\
\hline Technical Support (TS) \\
TS1 The e-learning system provides support when there is a technical problem. \\
TS2 & A phone line is available at any time to address technical problems with the e-learning system. \\
TS3 & Questions can be asked by email when a technical problem occurs with the e-learning system. \\
TS4 & The e-learning system provides answers to frequently asked questions about its use. \\
TS5 & $\begin{array}{l}\text { You can make online inquiries like in a chat room to the people of the technical support when } \\
\text { there is a problem with the e-learning system. }\end{array}$ \\
TS6 & $\begin{array}{l}\text { The support staff of the e-learning system has a positive predisposition or helping attitude when } \\
\text { consulted. }\end{array}$ \\
Computer Self-efficacy (CSE) \\
CSE1 I can complete learning tasks in the e-learning system if no one is around to tell me what to do. \\
CSE2 I can complete the tasks of teaching in the e-learning system if I had never used a computer \\
[2ystem like this before.
\end{tabular}


Table 1 (Cont.) Constructs - items

Social Influence (SI)

SI1

The directors of my career and faculty think I should participate in teaching activities based on the e-learning systems.

SI2

My colleagues at the faculty think I should be involved in teaching activities based on the e-learning system.

SI3 The university officials think I should participate in activities based on e-learning system.

$\mathrm{SI} 4$ Generally, I would like to do what my dean thinks I should do.

SI5

Perceived Enjoyment (PE)

PE1 The e-learning system has made that my stress due to tasks checking decrease because it does the work for me immediately.

PE2 I think that using e-learning systems to grade tasks, the score is given with the same

rigor to all.

PE3 I like more to grade tasks with e-learning systems than manually.

PE4 I find it entertaining e-learning systems.

PE5 I like to use the e-learning systems.

Satisfaction (S)

S1 I am pleased to use the e-learning systems as a learning tool.

S2 The e-learning system is efficient for the construction of knowledge.

S3 The e-learning system is efficient for the exchange of knowledge.

S4 I am satisfied with the interactivity of courses using e-learning systems.

S5 I am satisfied with the different evaluation options offered by the e-learning systems.

S6 I am satisfied with the use of e-learning systems, because it contributes to the development of transversal skills, such as teamwork.

Perceived Usefulness (PU)

PU1 In the courses I teach with the support of e-learning systems, my performance improves.

PU2 In the courses that teach with the support of e-learning systems, learning is effective.

PU3 In the courses I teach with the support of e-learning system, teaching becomes easier. In the courses I teach with the help of e-learning systems, the system is useful for

PU4 teaching.

I am satisfied with the different evaluation options offered by the e-learning system.

PU5 It is convenient in teaching, the use of e-learning systems.

Perceived easy of use (PEOU)

PEOU1 It is easy to operate the e-learning system.

PEOU2 The interaction with the e-learning system is clear and understandable.

PEOU3 The e-learning system is flexible to interact with.

PEOU4 It would be easy to be competent in the use of e-learning systems.

PEOU5 I consider that the e-learning system is easy to use.

Behavioral Intention (BI)

BI1 I will use the e-learning system in all the subjects I teach and that allow to use this resource.

BI2 It is important to use the e-learning system; I would recommend its use.

BI3 I will modify the teaching activities of my subjects to take advantage of the capabilities of e-learning system.

BI4 I will encourage my students and my own participation in the e-learning system, offering an activity based on participation in the forum of the subject.

BI5 I would like to use the e-learning system in the future if I had the chance.

System use (SU)

SU1 In terms of weekly hours, I tend to use the e-learning system the needed time to manage

the activities I propose in my subjects.

SU2 I spend a long time interacting with the e-learning system.

SU3 I get involved with the e-learning system.

SU4 I Join the e-learning system to interact with the course I teach at least once a day.

SU5 I frequently connect to participate in interactive activities (forums) I have proposed in the e-learning system.

SU6 
The 131 cases that were considered for the study were carried out by SPSS statistical software. As the overall level of missing data was $4.20 \%$, less than $10 \%$, may be used any method of imputation of missing data [34]. The mean replacement method was applied. The size of the resulting sample was suitable for analysis according to the criteria of E. van Raaij and J. Schepers (2008).

For data analysis the SEM technique focusing on partial least squares (PLS) was used. For this purpose the SmartPLS software version 3.2.4 was used [36].

\section{RESULTS}

To verify the validity and reliability of the measures, the loading factor was observed from confirmatory factor analysis (CFA) evaluating the measurement model [36]. To improve reliability, it was considered that must be retained the items with higher factor loadings to 0.707 [37], and that have a less dense questionnaire, the items are removed (CSE2 $=0.695$, CSE4 $=0.768$, CSE5 $=0.732$, CSE6 $=0.766$, $\mathrm{S} 4=0.895$, SU1 $=0.675$ y TS2 $=0.732$ ). Items with factor loadings that exceed the value of 0.707 were also eliminated, having into account that they were those ones with less loading factor within their respective constructs and that they were already assessed in other items. The local adjustment indexes, reliability, and average variance extracted (AVE) were examined as well. The factor loadings from the CFA provide evidence of convergent validity (all items load greater than 0.707 ). For reliability analysis, composite reliability was evaluated. Compound reliability values vary between 0.90 and 0.97 and therefore all are above the minimum value of 0.7 [38]. The fit measures can be found in Table 2 .

Table 2 Summary of measurement scales

\begin{tabular}{|c|c|c|c|c|c|}
\hline Constructs items & Mean & $\begin{array}{l}\text { Standard } \\
\text { deviation }\end{array}$ & $\begin{array}{c}\text { Factor } \\
\text { loading }\end{array}$ & $\begin{array}{l}\text { Composite } \\
\text { reliability }\end{array}$ & $\begin{array}{l}\text { Average } \\
\text { variance } \\
\text { extracted }\end{array}$ \\
\hline $\begin{array}{l}\text { Technical Support (TS) } \\
\text { TS1 } \\
\text { TS3 } \\
\text { TS4 } \\
\text { TS5 } \\
\text { TS6 }\end{array}$ & $\begin{array}{l}3.93 \\
4.21 \\
4.14 \\
3.75 \\
4.98\end{array}$ & $\begin{array}{l}2.13 \\
2.09 \\
1.99 \\
2.07 \\
1.90\end{array}$ & $\begin{array}{l}0.80 \\
0.88 \\
0.90 \\
0.81 \\
0.80\end{array}$ & 0.92 & 0.71 \\
\hline $\begin{array}{l}\text { Computer Self-efficacy (CSE) } \\
\text { CSE1 } \\
\text { CSE3 } \\
\text { CSE7 } \\
\text { CSE8 } \\
\text { CSE9 }\end{array}$ & $\begin{array}{l}5.41 \\
5.16 \\
5.86 \\
5.61 \\
5.54\end{array}$ & $\begin{array}{l}1.56 \\
1.61 \\
1.32 \\
1.41 \\
1.34\end{array}$ & $\begin{array}{l}0.82 \\
0.77 \\
0.88 \\
0.90 \\
0.86\end{array}$ & 0.93 & 0.72 \\
\hline $\begin{array}{l}\text { Social Influence (SI) } \\
\text { SI1 } \\
\text { SI2 } \\
\text { SI3 } \\
\text { SI4 } \\
\text { SI5 }\end{array}$ & $\begin{array}{l}5.43 \\
5.20 \\
5.61 \\
5.20 \\
5.65\end{array}$ & $\begin{array}{l}1.72 \\
1.67 \\
1.47 \\
1.60 \\
1.44\end{array}$ & $\begin{array}{l}0.84 \\
0.86 \\
0.88 \\
0.73 \\
0.71\end{array}$ & 0.90 & 0.65 \\
\hline $\begin{array}{l}\text { Perceived Enjoyment (PE) } \\
\text { PE1 } \\
\text { PE2 } \\
\text { PE3 } \\
\text { PE4 } \\
\text { PE5 }\end{array}$ & $\begin{array}{l}4.86 \\
5.40 \\
5.00 \\
5.12 \\
5.47\end{array}$ & $\begin{array}{l}1.83 \\
1.63 \\
1.90 \\
1.72 \\
1.64\end{array}$ & $\begin{array}{l}0.77 \\
0.77 \\
0.87 \\
0.87 \\
0.90\end{array}$ & 0.92 & 0.70 \\
\hline $\begin{array}{l}\text { Satisfaction (S) } \\
\text { S1 } \\
\text { S2 } \\
\text { S3 } \\
\text { S5 } \\
\text { S6 }\end{array}$ & $\begin{array}{l}5.60 \\
5.56 \\
5.67 \\
5.47 \\
5.57\end{array}$ & $\begin{array}{l}1.43 \\
1.42 \\
1.36 \\
1.38 \\
1.43\end{array}$ & $\begin{array}{l}0.92 \\
0.95 \\
0.94 \\
0.92 \\
0.92\end{array}$ & 0.97 & 0.86 \\
\hline $\begin{array}{l}\text { Perceived Usefulness (PU) } \\
\text { PU1 } \\
\text { PU2 } \\
\text { PU3 } \\
\text { PU4 } \\
\text { PU5 }\end{array}$ & $\begin{array}{l}5.52 \\
5.59 \\
5.55 \\
5.62 \\
5.82\end{array}$ & $\begin{array}{l}1.52 \\
1.32 \\
1.47 \\
1.30 \\
1.28\end{array}$ & $\begin{array}{l}0.91 \\
0.94 \\
0.93 \\
0.93 \\
0.90\end{array}$ & 0.97 & 0.85 \\
\hline
\end{tabular}


Table 2 (Cont.) Summary of measurement scales

\begin{tabular}{|c|c|c|c|c|c|}
\hline Constructs items & Mean & $\begin{array}{l}\text { Standard } \\
\text { deviation }\end{array}$ & $\begin{array}{l}\text { Factor } \\
\text { loading }\end{array}$ & $\begin{array}{c}\text { Composite } \\
\text { reliability }\end{array}$ & $\begin{array}{l}\text { Average } \\
\text { variance } \\
\text { extracted }\end{array}$ \\
\hline Perceived easy of use (PEOU) & & & & 0.97 & 0.88 \\
\hline $\begin{array}{l}\text { PEOU1 } \\
\text { PEOU2 } \\
\text { PEOU3 } \\
\text { PEOU4 } \\
\text { PEOU5 }\end{array}$ & $\begin{array}{l}5.50 \\
5.50 \\
5.46 \\
5.63 \\
5.45\end{array}$ & $\begin{array}{l}1.40 \\
1.43 \\
1.44 \\
1.45 \\
1.50\end{array}$ & $\begin{array}{l}0.89 \\
0.95 \\
0.95 \\
0.94 \\
0.94\end{array}$ & & \\
\hline Behavioral Intention (BI) & & & & 0.97 & 0.86 \\
\hline $\begin{array}{l}\text { BI1 } \\
\text { BI2 } \\
\text { BI3 } \\
\text { Bl4 } \\
\text { Bl5 }\end{array}$ & $\begin{array}{l}5.92 \\
5.82 \\
5.72 \\
5.79 \\
5.87\end{array}$ & $\begin{array}{l}1.33 \\
1.35 \\
1.33 \\
1.25 \\
1.33\end{array}$ & $\begin{array}{l}0.94 \\
0.94 \\
0.93 \\
0.91 \\
0.93\end{array}$ & & \\
\hline System Use(SU) & & & & 0.95 & 0.80 \\
\hline $\begin{array}{l}\text { SU2 } \\
\text { SU3 } \\
\text { SU4 } \\
\text { SU5 } \\
\text { SU6 }\end{array}$ & $\begin{array}{l}4.99 \\
5.25 \\
5.24 \\
4.87 \\
5.37 \\
\end{array}$ & $\begin{array}{l}1.48 \\
1.48 \\
1.66 \\
1.76 \\
1.56 \\
\end{array}$ & $\begin{array}{l}0.88 \\
0.92 \\
0.89 \\
0.87 \\
0.91\end{array}$ & & \\
\hline
\end{tabular}

To verify the discriminant validity, the Fornell and Larcker (1981) test was applied. The procedure dictates that the square root of the AVE of each construct exceeds the shared correlation between the construct and other constructs in the model in order to obtain the discriminant validity. Table 3 shows the details of this analysis. All constructs successfully passed the test; the square root of the AVE (on the diagonal) is greater than the cross-correlations with other constructs. All eligibility criteria exceed threshold levels commonly suggested in the literature and show good reliability and validity of all constructs.

Statistical significance of the relations in the model was assessed using SmartPLS 3.2.4 [36] with a bootstrap procedure with 500 resamples. We find a direct positive impact of $\mathrm{BI}$ on $\mathrm{SU}$, but no direct impact of S. PU and PEOU both have a direct positive impact on BI. PE, PEOU and SI have a direct positive impact on PU, but no direct impact of TS and CSE. PE and CSE both have a direct positive impact on PEOU, but no direct impact of TS. PU has a direct positive impact on S.

Table 3 Discriminant and convergent validity of the constructs

\begin{tabular}{llllllllll}
\hline & BI & CSE & PE & PEOU & PU & S & SI & SU & TS \\
\hline BI & $\mathbf{0 . 9 3 0}$ & & & & & & & & \\
CSE & 0.659 & $\mathbf{0 . 8 4 9}$ & & & & & & & \\
PE & 0.703 & 0.548 & $\mathbf{0 . 8 3 8}$ & & & & & & \\
PEOU & 0.713 & 0.679 & 0.692 & $\mathbf{0 . 9 3 7}$ & & & & & \\
PU & 0.768 & 0.554 & 0.760 & 0.734 & $\mathbf{0 . 9 2 2}$ & & & & \\
S & 0.786 & 0.580 & 0.771 & 0.686 & 0.866 & $\mathbf{0 . 9 3 0}$ & & & \\
SI & 0.571 & 0.547 & 0.401 & 0.455 & 0.514 & 0.545 & $\mathbf{0 . 8 0 8}$ & & \\
SU & 0.674 & 0.549 & 0.639 & 0.670 & 0.566 & 0.552 & 0.436 & $\mathbf{0 . 8 9 4}$ & \\
TS & 0.430 & 0.577 & 0.487 & 0.495 & 0.480 & 0.505 & 0.532 & 0.442 & $\mathbf{0 . 8 4 0}$ \\
\hline
\end{tabular}

In contrast to covariance structure analysis modeling approaches, PLS has no proper single goodness-of-fit measure, because its primary objective is maximization of variance explained, not minimization of the difference between the observed and the reproduced covariance matrixes. The quality of a PLS model can be determined by examining the $\mathrm{R}^{2}$ values of the endogenous constructs [40]. The model explains $46 \%$ of variance in SU, $64 \%$ of variance in $\mathrm{BI}, 75 \%$ of variance in $\mathrm{S}, 69 \%$ of variance in PU and $61 \%$ of variance in PEOU. Fig. 3 shows a graphical representation of the outcomes of the model test. 


\section{DISCUSSION AND CONCLUSION}

The analysis showed the predictive relevance and validity of the model to evaluate the acceptance of e-learning systems among teachers in Ecuador. One of the main reasons for this finding may be the ease with which teachers use technology today. This is evidenced by the positive influence of CSE on PEOU in this study.

PU stands out as the most important factor influencing the behavior of the intention to use e-learning systems in the Ecuadorian teachers. The social influence has a direct effect on the perceived usefulness.

Our study suggests that the core TAM relationships hold just as well in an Ecuadorian setting as they do in other countries. The majority of hypothesized relationships are supported by the data.

This work is characterized by the inclusion of SI, PE, S and CSE. This highlights that the application of e-learning systems should focus on the social context and not on technology.

Among the prominent findings in this study, it is the positive influence of PE on PU and PEOU. It is suggested to conduct a nationwide study that also involves the views of students, which should update the questionnaire.

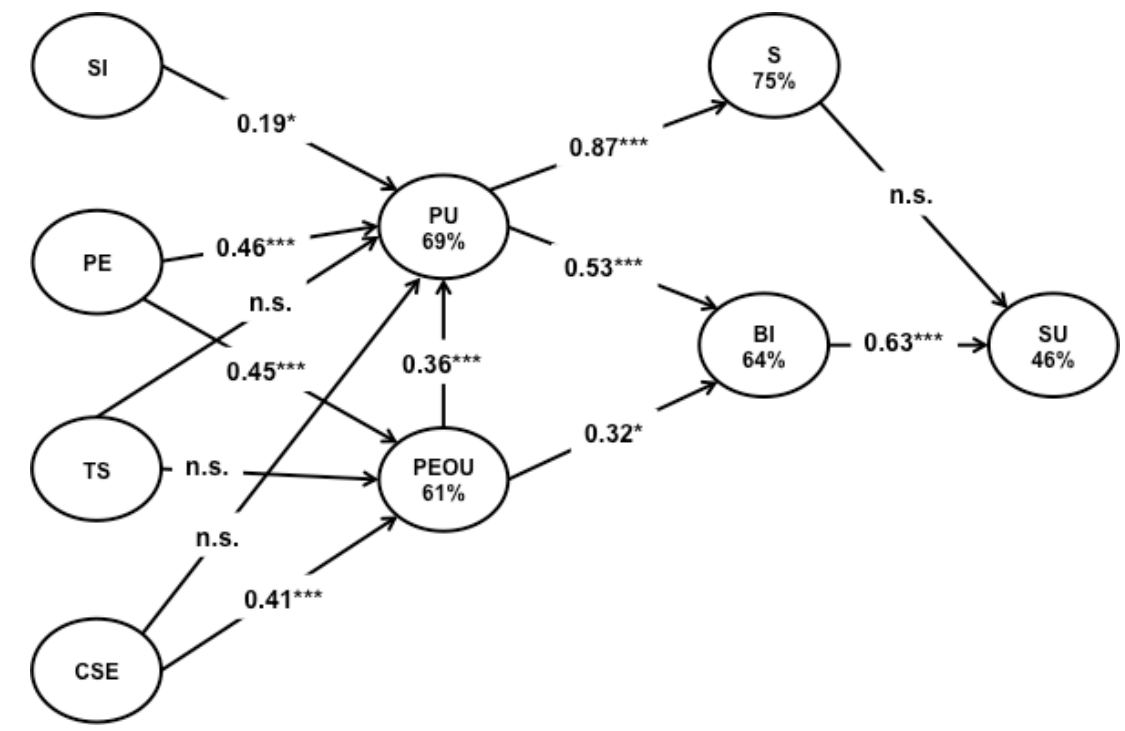

Fig. 3. PLS results. Notes: Variance explained (R2) between brackets. ${ }^{*}$ Path coefficient significant at the 0.05 level; ${ }^{* *}$ at the 0.01 level; ${ }^{* *}$ at the 0.001 level.

\section{REFERENCES}

[1] V. Lobato Rubio, "Caracterización del conocimiento en PYMES que realizan proyectos de TIC: un modelo de análisis y valoración." Universidad de Oviedo, Oviedo, 20-Nov-2008.

[2] C. D. Melas, L. a Zampetakis, A. Dimopoulou, and V. Moustakis, "Modeling the acceptance of clinical information systems among hospital medical staff: an extended TAM model.," J. Biomed. Inform., vol. 44, no. 4, pp. 553-64, Aug. 2011.

[3] Y. H. Lee, Y. C. Hsieh, and C. N. Hsu, "Adding Innovation Diffusion Theory to the Technology Acceptance Model: Supporting Employees' Intentions to use E-Learning Systems," Educ. Technol. Soc., vol. 14, no. 4, pp. 124-137, 2011.

[4] C. L. Oprea, "The Internet - A Tool for Interactive Learning," Procedia - Soc. Behav. Sci., vol. 142, pp. 786-792, 2014.

[5] L. A. Mallak, "Challenges in Implementing e-Learning," in International Conference on Management of Engineering and Technology, 2001, no. October, pp. 298-299.

[6] K. M. "Marty" Fletcher, "Self-efficacy as an evaluation measure for programs in support of online learning literacies for undergraduates," Internet High. Educ., vol. 8, no. 4, pp. 307-322, Oct. 2005. 
[7] E. W. T. Ngai, J. K. L. Poon, and Y. H. C. Chan, "Empirical examination of the adoption of WebCT using TAM," Comput. Educ., vol. 48, no. 2, pp. 250-267, 2007.

[8] J. Dutton, M. Dutton, and J. Perry, "How do online students differ from lecture students?," J. Asynchronous Learn. Networks, vol. 6, no. 1, pp. 1-20, 2002.

[9] N. Li and G. Kirkup, "Gender and cultural differences in Internet use: A study of China and the UK," Comput. Educ., vol. 48, no. 2, pp. 301-317, Feb. 2007.

[10] P. Legris, J. Ingham, and P. Collerette, "Why do people use information technology ? A critical review of the technology acceptance model," vol. 40, pp. 191-204, 2003.

[11] F. D. Davis, "Perceived Usefulness, Perceived Ease of Use, and User Acceptance of Information Technology," MIS Q., vol. 13, no. 3, pp. 319-340, 1989.

[12] F. D. Davis, R. P. Bagozzi, and R. P. Warshaw, "User Acceptance of Computer Technology: A Comparison of Two Theoretical Models," Manage. Sci., vol. 35, no. 8, pp. 982-1003, 1989.

[13] F. D. Davis, "Davis-User acceptance of information technology: system characteristics user perceptions, and behavioral impacts," Int. J. Man-Machine Stud., vol. 38, pp. 475-487, 1993.

[14] V. Venkatesh and F. D. Davis, "A Model of the Antecedents of Perceived Ease of Use: Development and Test," Decis. Sci., vol. 27, no. 3, pp. 451-481, 1996.

[15] N. Park, K. M. Lee, and P. H. Cheong, "University instructors' acceptance of electronic courseware: An application of the technology acceptance model," J. Comput. Commun., vol. 13, no. 1, p. 25, 2007.

[16] B. Sumak, M. Hericko, and M. Pusnik, "A meta-analysis of e-learning technology acceptance: The role of user types and e-learning technology types," Comput. Human Behav., vol. 27, no. 6, pp. 2067-2077, 2011.

[17] N. Kripanont, "Using a Technology Acceptance Model to Investigate Academic Acceptance of the Internet," J. Bus. Syst. Gov. Ethics, vol. 1, no. 2, pp. 13-28, 2006.

[18] T. Feneche, "Using perceived ease of use and perceived usefulness to predict accptance of the world wide web," Comput. Networks ISDN Syst., vol. 30, pp. 629-630, 1998.

[19] H. L. Liao and H. P. Lu, "Richness versus parsimony antecedents of technology adoption model for e-learning websites," in Advances in Web Based Learning - Icwl 2008, Proceedings, vol. 5145, F. Li, J. Zhao, T. K. Shih, R. Lau, Q. Li, and D. McLeod, Eds. Berlin: Springer-Verlag Berlin, 2008, pp. 8-17.

[20] R. E. Schumacker and R. G. Lomax, A Beginner's Guide to Structural Equation Modeling: Third Edition, 3rd ed. New York - USA: Routledge, 2010.

[21] M. Kocaleva, "Model of e-Learning Acceptance and Use for Teaching Staff in Higher Education Institutions," I.J. Mod. Educ. Comput. Sci., vol. 4, no. April, pp. 23-31, 2015.

[22] A. Padilla-meléndez, A. R. Águila-obra, and A. Garrido-moreno, "Empleo de moodle en los procesos de enseñanza-aprendizaje de dirección de empresas: nuevo perfil del estudiante en el eees," Educ. XX1, vol. 18, no. 1, pp. 125-146, 2015.

[23] R. A. Arteaga and A. D. Duarte, "Motivational factors that influence the acceptance of Moodle using TAM," Comput. Human Behav., vol. 26, no. 6, pp. 1632-1640, 2010.

[24] M. Y. Yi and Y. Hwang, "Predicting the use of web-based information systems: self-efficacy, enjoyment, learning goal orientation, and the technology acceptance model," Int. J. Hum. Comput. Stud., vol. 59, no. 4, pp. 431-449, Oct. 2003.

[25] C. Rey Martín, "La satisfacción del usuario: Un concpto en alza," An. Doc., vol. 3, pp. 139-153, 2000.

[26] R. Mbarek and F. Zaddem, "The examination of factors affecting e-learning effectiveness," Int. J. Innov. Appl. Stud., vol. 2, no. 4, pp. 423-435, 2013.

[27] P. Sanjuán Suárez, A. M. Pérez García, and J. Bermúdez Moreno, "Escala de autoeficacia general: Datos psicométricos de la adaptación para población española," Psicothema, vol. 12, no. SUPPL. 2, pp. 509-513, 2000. 
[28] A. Tarhini, K. Hone, and X. Liu, "Factors Affecting Students ' Acceptance of e-Learning Environments in Developing Countries : A Structural Equation Modeling Approach," Int. J. Inf. Educ. Technol., vol. 3, no. 1, pp. 54-59, 2013.

[29] C. Weng and C. Tsai, "Social support as a neglected e-learning motivator affecting trainee' $s$ decisions of continuous intentions of usage," Australas. J. Educ. Technol., vol. 31, no. 2, pp. 177-192, 2015.

[30] W. S. Lin, "Perceived fit and satisfaction on web learning performance: IS continuance intention and task-technology fit perspectives," Int. J. Hum. Comput. Stud., vol. 70, no. 7, pp. 498-507, 2012.

[31] J.-G. Lay, Y.-W. Chen, and Y.-L. Chi, "GIS Adoption Among Senior High School Geography Teachers in Taiwan," J. Geog., vol. 112, no. 3, pp. 120-130, May 2013.

[32] D. Findik and C. O. Ş. Kunçay, "A MODEL FOR INSTRUCTORS ' ADOPTION OF LEARNING MANAGEMENT SYSTEMS : EMPIRICAL VALIDATION IN HIGHER EDUCATION CONTEXT," Middle East Technical University, 2009.

[33] B. Peral Peral, J. Arenas Gaitán, and M. Á. Ramón-Jerónimo, "Technology Acceptance Model y mayores: ¿la educación y la actividad laboral desarrollada son variables moderadoras?," Rev. Española Investig. en Mark. ESIC, vol. 18, no. 1, pp. 43-56, 2014.

[34] J. F. Hair, W. C. Black, B. J. Babin, and R. E. Anderson, Multivariante Data Analysis A Global Perspective, Seventh. 2010.

[35] E. M. Van Raaij and J. J. L. Schepers, "The acceptance and use of a virtual learning environment in China," Comput. Educ., vol. 50, no. 3, pp. 838-852, 2008.

[36] G. D. Garson, Partial Least Squares: Regression \& Structural Equation Models, 2016th ed. Asheboro - USA: Statistical Associates Publishing, 2016.

[37] E. G. Carmines and R. A. Zeller, Reliability and validity assessment, vol. 17. Berverly Hill - USA: McCune, Sara, 1979.

[38] J. Henseler, C. Ringle, and M. Sarstedt, "Using partial least squares path modeling in advertising research: basic concepts and recent issues," in Handbook of research on International Advertising, no. December, 2012, pp. 252-276.

[39] C. Fornell and D. F. Larcker, "Evaluating Structural Equation Models with Unobservable Variables and Measurement Error," J. Mark. Res., vol. 18, no. 1, pp. 39-50, Feb. 1981.

[40] J. Hulland, "Use of partial least squares (PLS) in strategic management research: a review of four recent studies," Strateg. Manag. J., vol. 20, no. 2, pp. 195-204, Feb. 1999. 